\title{
Prospek Pemberantasan Korupsi: Perimbängan Kewenangan KPK dengan Institusi Penegak Hukum
}

\author{
Jawahir Thontowi \\ Universitas Islam Indoñesia
}

This study reveals that law enforcement against corruption crimes carried out by the AntiCorruption Committee (Komisi Pemberantasan Korupsi, hereinafter KPK) has not been fully effective to reduce the crimes. However, the KPK remains important to exist. Nevertheless, its roles need to be reduced in order to create balance of authorities between the $K P K$ and other institutions that are involved in dealing with corruption eradication. Polices and prosecutors should remain having their own jurisdiction in local government levels to eradicate corruption, and the establishment of special task force, such as Police Task Force, to investigate corruption case should be taken into account.

Keywords: law enforcement, corruption, balance, task force

Qjak reformasi menggelinding, 1998 , Okemauan politik (political will) pemerintah untuk melakukan pemberantasan terhadap kejahatan korupsi telah menjadi program prioritas nyata. Wujud kemauan politik tersebut dibuktikan dengan disyahkannya UU 28 tahun 1999 tentang Penyelenggaraan Negara yang Bersih, Bebas Korupsi, Kolusi dan Nepotisme, dan UU No 31/1999 (diubah dengan UU No 20 tahun 2001) tentang Pemberantasan Tindak Pidana Korupsi. Selain itu, UU No 30/2002 tentang Komisi Pemberantasan Tindak Pidana Korupsi (KPK) memiliki peran sangat strategis.

Dalam implementasinya, sëbagian masyarakat masih belum memuaskan. Kesenjangan kewenangan antara KPK dengan penegak hukum, lemahnya dukungan politis pemerintah terbatasnya fasilitas umur dan KPK masih relatif muda merupakan faktor faktor penyebab keter- batasan tersebut. Sehingga dapat dimaklumi sekiranya peran KPK sampai saat ini belum optimal sebagaimana diharapkan masyarakat Indonesia pada umumnya.

Di satu pihak, fungsi KPK, sebagai lembaga Superbody institusi penegak hukum kejahatan korupsi telah mendapatkan pembenaran juridis. Sehingga kehadiran KPK, umumnya cenderung menimbulkan kontorversial dalam praktek penegakan hukum kejahatan korupsi di tingkat lapangan. Terutama, adanyà kesan tebang pilih yang tidak dapat dihilangkan jejaknya. Di pihak lain, peran institusi penegak hukum, seperti kepolisian, kejaksaan, dan pengadilan merasa terkurangi. Sebab, dalam waktu lalu merupakan kewenangan bersama polisi, jaksa dan pengadilan umum. Akan tetapi, sejak keluarnya UU No.31/2002, 'kejahatan korupsi, dalam ukuran tertentu (di atas 1 miliar) merupakan jurisdiksi kompetensi 
KPK. Sehingga, pihak kepolisian, yang merupakan pintu gerbang proses penyelidikan dan penyidikan dalam penegakan hukum dalam tindak pelanggaran dan kejahatan, termasuk kejahatan korupsi menjadi amat terkurangi. Dalam kejahatan korupsi tertentu, polisi tidak dapat melakukan penyelidikan dan penyidikan di tingkat lapangan, menempatkan situasi kontra-produktif bagi citra kepolisian. Ketidak wenangan polisi untuk melakukan penyelidikan dan penyidikan dalam kejahatan korupsi di tingkat kabupaten atau kotamadya, terkadang membuat masyarakat lokal begitu mudah mendiskreditkan peran penegak hukum, khususnya pihak kepolisian.

Kompleksitas kejahatan korupsi mustahil dapat dicari jalan keluarnya hanya dengan pendekatan parsial. Dalam ketentuan hukum internasional, selain korupsi sebagai kejahatan luar biasa akibat adanya penyalahgunaan-kewenangan (abuse of power) yang telah menggoyahkan sendisendi kehidupan bernegara. Juga kejahatan korupsi menjadi sangat sulit diberantas karena muara utamanya berada pada institusi penegak hukum. Hasil Survei Lembaga Transparansi Internasional (TI), mengungkapkan bahwa Lembaga-Lembaga vertical, (Polisi, Peradilan, Pajak, Imigrasí, Bea Cukai, Militer dII), masih dipersepsikan sangat korup. Menurut versi TI, bahwa lembaga peradilan merupakan lembaga paling tinggi tingkat inisiatif meminta suap $(100 \%)$, disusul Bea Cukai (95\%), Imigrasi (90\%) BPN (84\%) Polisi (78\%) dan Pajak $(76 \%)$.

Prosentase tingkat kejahatan korupsi di kalangan penegak hukum tidak akan berkembang mustahil tanpa kontribusi budaya masyarakat. Terutama terkait dengan praktek budaya upeti, suap dan hutang budi, juga jalan pintas untuk memperoleh pelayanan yang lebih cepat dan diutamakan. Dalam penelitiannya, Farouk Muhammad mengungkapkan bahwa faktor-faktor penyebab yang dapat menjelaskan fenomena korupsi adalah penyalah gunaan kekuasaan, utamanya terkait dengan fakor rendahnya kesejahteraan. Gaji penegak hukum, terutama polisi sangat tidak mencukupi untuk suatu jaminan hidup yang layak merupakan fakta yang tidak dapat disangkal. Meskipun faktor penyebabnya tidak harus semata-mata atas alasan kesejahteraan, motivasi memperkaya diri akan tetap relevan sebagai faktor pendorong dalam timbulnya kejahatan korupsi (Farouk Muhammad,2007:5).

Kenyataan secara faktual penyebab korupsi begitu kompleks, maka kebijakan pemerintah harus dilakukan secara terpadu, baik dalam arti pemahaman konseptual, maupun secara strategi ope-rasional penegakannya di lapangan. Tanpa adanya keterpaduan antara perumusan konsepsi, strategi dan metode pendekatan, maka peran dan fungsi penegak hukum akan terganggu oleh adanya konflik kepentingan yang tidak dapat dikendalikan. Untuk memberdayakan pentingnya paradigma baru tentang pemberantasan kejahatan korupsi di Indonesia, maka diperlukan adanya alokasi manajemen kewenangan antara KPK dengan institusi penegak hukum (Polisi, Jaksa dan Pengadilan). Bagaimana upaya yang harus dilakukan agar KPK dan penegak hukum lainnya, secara simultan dapat meningkatkan efektifitas dalam melakukan pemberantasan terhadap kejahatan korupsi, sebagai kejahatan luar biasa (Extra Ordinary Crime) yang pelaksanaannya dilakukan secara optimal, intensif, profesional serta berkesinambungan (UU No.30, 2007:1-25). 
Prospek Pemberantasan Korupsi: Perimbangan Kewenangan...; Jawahir Thontowi

\section{Sistem Hukum Terkait Kejahatan Korupsi}

Kejahatan korupsi yang semula dipandang sebagai kajahatan biasa (Ordinary Crime), masyarakat internasional saat ini, sepakat untuk menempatkan kejahatan korupsi sebagai kejahatan luar biasa (Extra Ordinary Crime). Keadaan luar biasa tersebut meniscayakan adanya tindakan dan penanganan secara luar biasa pula. Namun, penanganan yang luar biasa tidaklah berarti dapat keluar dari koridor the rule of law. Asas-asas hukum yang selama ini telah menjadi bagian tak terpisahkan dari sistem pemidanaan yang berkeadilan harus tetap dapat diberlakukan.

Dalam perspektif hukum nasional paska reformasi, UU No 31 tahun 1999, tentang Tindak Pidana Korupsi rumusan kejahatan korupsi lebih komprehensif. Kejahatan korupsi dipandang, sebagai setiap orang yang secara melawan hukum memperkaya diri sendiri atau orang lain, atau suatu korporasi, yang dapat merugikan keuangan negara atau perekonomian negara. Secara substansif, pasal tersebut mengandung perbuatan seseorang, baik aparat pemerintah atau bukan, tetapi perbuatan yang menyalahi kewenangan tersebut, baik secara keseluruhan maupun sebagian dapat berakibat timbulnya kerugian negara.

Seiring dengan itu, Muhammad Farouk dalam kajiannya menyebutkan bahwa bentuk bentuk korupsi ke dalam dua sifat.(1) general dengan misal: merajalela dimanamana, relatif terbuka (mudah diketahui), menyangkut publik (banyak orang), dengan jumla uang yang relatif kecil serta pada umumnya melibatkan pegawai/pejabat eselon rendah dan didorong oleh kebutuhan primer baik pribadi maupun institusi. (2) Spesifik/terbatas: hanya pada kesempatan/ menyangkut kasus tertentu (eksklusif), relatif tertutup dengan modus yang canggih (sulit dibuktikan), melibatkan orang tertentu (bisnis) dan pejabat yang berwewenang yang lebih tinggi dengan jumlah uang yang relatif besar dan biasanya lebih didorong oleh kesepakatan dari pada primer (Farouk Muhammad, 2007:5).

Seiring dengan itu Romli Atmasasmita, sebagai pakar hukum pidana internasional menegaskan bahwa strategi pemberantasan korupsi di Indonesia harus menggunakan empat (4) pendekatan yaitu pendekatan hukum, pendekatan moralistik dan keimanan, pendekatan edukatif, dan pendekatan sosio-kultural. Begitu kompleksnya penyebab kejahatan korupsi, maka pembenrantasan korupsi dengan pendekatan konvensional dipandang sudah tidak relevan lagi. Sehingga modus operasi tindak pidana korupsi dalam sistem hukum pidana kita harus dijadikan suatu kejahatan luar biasa (Extra Ordinary Crimes). Sebab, upaya mendahulukan kepentingan bangsa dan negara dalam upaya memerangi kejahatan korupsi merupakan bentuk kewajiban negara untuk memenuhi tuntutan hak-hak asasi sosial ekonomi masyarakat sebagaimana dikemukakan oleh pasal 29 Deklarasi PBB (Romli Atmasasmita, 2004: 13).

Dalam perspektif intemasional, yang direkomendasikan oleh PBB, melalui Centre for Intemational Crime Prevention secara lebih rinci bahwa kejahatan koruspi sangat terkait dengan sepuluh perbuatan pengadaan barang dan jasa. Hal tersebut antara lain pemberian suap (Bribary), penggelapan (embezzlement), pemalsuan (Fraud), pemerasan (extortion), penyalahgunaan jabatan atau wewenang (abuse of discretion), pertentangan kepentingan/memiliki usaha sendiri (intemal trading), pilih kasih atau tebang pilih (favoritisme), menerima 
komisi, nepotisme (nepotism), kontribusi atau sumbangan ilegal (illegal contribution). Secara faktual, perbuatan korupsi yang dapat menimbulkan kerugian negara ditemukan di lapangan hampir $90 \%$ kejahatan tindak pidana korupsi dilakukan oleh pejabat publik.

Kemauan politik (political will) kebijakan negara (state policy) yang terkait dengan keterpaduan pemberantasan korupsi antara lain diwujudkan melalui kebijakan sebagai berikut. (1). Peraturan pencegahan terkait dengan harta kekayaan pejabat sebelum dan sesudah menjabat diatur dengan UU No 28 Tahun 1999 tentang Penyelenggaraan Negara Yang Bersih dan Bebas dari Korupsi, Kolusi, dan Nepotisme. (2) Pelaksanaan pencegahan diwujudkan dalam insturumen kebijakan Presiden dan Menteri yang lain, Surat Edaran Menteri Negara PAN Nomor: SE/03/M.PAN/01/2005 tahun 2004, Perihal Laporan Harta Keka-yaan Penyelenggara Negara (LHKPN), diperbaharui dengan Surat Edaran Menteri Negara PAN Nomor: SE/05/ M.PAN/04/2006 Tentang Laporan Harta Kekayaan Penye-lenggara Negara. Disempurnakan lagi dengan Surat Edaran Menteri Negara Nomor: SE/16/M.PAN/04/ 2006 Tentang Tindak Lanjut Penyampaian Laporan Harta Kekayaan Penyelenggara Negara. Kebi-jakan pemerintah terkait dengan pening-katan kualitas SDM-nya yaitu melalui Surat Edaran Menteri PAN Nomor SE/06/M.PAN/04/2006. Tentang Pelaksanaan Fakta Integritas. Terakhir, suatu kebijakan yang relevan disebutkan adalah dikeluarkannya Instruksi Presiden No 5 tahun 2004, tentang Pencepatan Pemberantasan Korupsi, yang kemudian ditindak lanjuti dengan Keputusan Menteri Negara Pendayagunaan Aparatur Negara, No Kep/120/M.PAN/4/2006 tentang Perubahan Keputusan Menteri Negara PAN No Kep/194/M.PAN/8/2005 tentang
Pedoman Umum Kordinasi, Monitoring dan Evaluasi Pelaksanaan Pencepatan Pemberantasan Korupsi.

\section{Tantangan KPK dalam \\ Pemberantasan Tindak Pidana Korupsi}

Terkait dengan sistem hukum penanggulangan tindak pidana kejahatan korupsi, keberadaan Komisi Pemberantasan Korupsi telah menjadi ikon nasional dan intemasional di Indonesia. Bilamana pada masa lalu, ketentuan normatif mengenai pemberantasan tindak pidana korupsi telah dipandang kurang lengkap peraturan hukumnya. Oleh karena ketiadaan lembaga penegak hukum khusus (Special Task Force for Combating Corrution) menjadi penyebab utama penegakan hukum tindak pidana korupsi menjadi tidak fektif. Karena itu, urgensi dibentuknya KPK, melalui UU No 20 Tahun 2002 tentang Komisi Pemberantasan Tindak Pidana Korupsi diharapkan dapat mewujudkan masyarakat yang adil da makmur dsan sejahtera berdasarkan Pancasila dan UUD 1945. Dengan memberikan amanah dan tanggungjawab kepada KPK untuk melakukan peningkatan pemberantasan tindak pidana korupsi, lebih profesional, intensif, tindak pidana korupsi telah merugikan keuangan negara, dan juga menghambat pembangunan nasional.

Kedudukan KPK sebagai institusi hukum yang strategis oleh karena memiliki kewenangan lebih kredible dan profesional UU No 30 tahun 2002 tentang Komisi Pemberantasan Tindak Pidana Korupsi: Pertama, status dan sifat serta kewenangan KPK sebagai lembaga negara yang dalam pelaksanaan tugas dan wewenangnya bersifat independen dan bebas dari pengaruh kekuasaan manapun (pasal 3). Kedua; KPK secara khusus dibentuk dengan tujuan 
Prospek Pemberantasan Korupsi: Perimbangan Kewenangan...; Jawahir Thontowi

meningkatkan daya guna dan hasil guna terhadap upaya pemberantasan korupsi (pasal 4). Ketiga, asas-asas yang dipergunakan KPK dalam menjalan tugasnya yaitu, kepastian hukum, keterbukaan, akuntabilitas, kepentingan umum, dan proporsionalitas. Keempat, kewenangan KPK yang melebihi penegak hukum konvensional adalah terletak pada pasal enam (6) yaitu KPK mempunyai tugas, (a) kordinasi dengan instansi yang berwewenang melakukan pemberantasan tindak pidana korupsi; (b) supervisi terhadap instansi yang berwewenang dalam melakukan pemberantasan korupsi (c), melakukan penyelidikan dan penyidikan, dan penuntutan terhadap tindak pidana korupsi, (d) melakukan tidakan pencegahan tindak pidana korupsi; dan (e) melakukan monitor terhadap penyelenggaraan pemerintahan negara.

Dari ketentuan UU inilah kemudian timbul kesan bahwa KPK dalam kaitannya dengan kompetensi tugas dan fungsi di lapangan dipandang sebagai Lembaga Negara Terkuat (Superbody). Status dan sifat KPK yang terkesan Superbody tersebut antara lain dikarenakan tiga ciri dominan. Pertama, KPK sebagai lembaga Negara (Special State Agency) yang secara khusus melakukan tugas dalam tindakan pidana korupsi. Kedua, keberadaan KPK melebehi - peran dan fungsi yang berada pada lembaga penegak hukum, antara Polisi, Kejaksaan, dan bahkan dengan lembaga-lembaga negara lainnya. KPK memiliki kewenangan untuk tidak saja melakukan kordinasi dan supervisi dengan institusi penegak hukum dan lembaga negara lainnya dalam tindak pidana korupsi. Ketiga, KPK dapat menyatukan tugas dan fungsi yang berada dalam kewenangan Kepolisian untuk penyelidikan dan penyidikan, Kejaksaan dalam hal penyidikan dan penuntutan. KPK dalam (pasal 11) mem-batasi segala tugas dan kewenanganya terhadap kasus kenuian negara dengan mominal Rp 1.000.000.000,(Satu Milyar). Namun, tiadanya sanksi hukuman yang lebih berat, seperti adanya hukuman mati diberlakukan berbagai negara seperti China adalah merupakan alat pengerem kejahatan korupsi juga termurah yang melemahkan keberadaan UU KPK (Kamri,2005:50).

Apakah tugas KPK sebagaimana selama ini diperankan telah memenuhi tuntutan masyarakat. Sebagaimana masyarakat memandang KPK yang oleh UU ditempatkan sebagai lembaga negara extra power dalam perjalanannya selama tiga tahun belum juga memperlihatkan hasil yang menggembirakan. Tanpa mengurangi makna dan arti kehadiran KPK dalam sistem penegakan hukum pidana di Indonesia, sebagaimana juga timbul di berbagai negara seperti Thailand, Singapura dan juga Malaysia dan Australia, KPK selain memperoleh peluang juga tantangan yang tidak cukup ringan. Terdapat empat persoalan utama yang dihadapi KPK yang kemudian peran dan fungsinya belum dapat diperoleh secara optimal sesuai dengan UU.

Pertama, tantangan internal di kalangan penegak hukum. Kecemburuan kelembagaan ini tidak dapat dhindarkan karena maksud dan tujuan dari UU Pembentukan KPK inkonsisten dengan ketentuan UU Kepolisian dan Kejaksaan. Misalnya, dalam konteks penyidikan dan penuntutan yang semula menjadi kewenangan Kepolisian dan Kejaksaan sepertinya telah memberikan peluang akan tak terbatasnya kewenangan KPK, meskipun jumlah 1 Milyar (pasal 11) cukup jelas. Namun, dalam arti pembagian dan pemisahan kewenangan tampak kurang konsisten dan berpeluang UU membuat kevacuman hukum dalam mensinergikan fungsi kerjasama di satu pihak, KPK dan 
pihak lain dengan Polisi dalam konteks penyelidikan dan penyidikan.

Sungguh memprihatinkan ketika penegakan hukum, khususnya kepolisian, kejaksaan, dan pengadilan tidak kompak dalam melaksanakan tugasnya menerapkan hukum terhadap suatu kasus yang sedang dimimpikan masyarakat.Mahfud MD dengan tegas menyoroti kasus pembebasan Adeline Lies oleh pengadilan di Medan, Sumatera Utara, dan berikutnya dilepaskan segera setelah putusan itu dikeluarkan merupakan pelecehan terhadap penegakan hukum Indonesia. Sehingga tidaklah mengherankan sekiranya peristiwa pembebasan Adeline telah menorehkan sejarah kelam penegakan hukum di era Kabinet Indonesia bersatu. Tepat jika terdapat pendapat, yang menyarankan agar Polri harus bersabar akan persitiwa itu. Bukankah tahun 2007, awal untuk menangkap Adeline, harus menggunakan Red Notice, Interpol, dimana keduataan RI yang berada di RRC turut serta terlibat dalam proses penangkapan.

Setelah petugas polisi all outmela-kukan penangkapan dan proses hukum sesuai dengan Hukum Acara Pidana kita, lalu penegakhukum lainnya menerapkan hukum tidak sesuai dengan harapan polisi, dan masyarakat. Dalam harian KOMPAS, tajuknya, dengan gamblang mengkritik posisi hakim di pengadilan yang memiliki kebebasan dalam penafsirkan dan menrapkan hukum. Proses peradilan amat panjang. Mulai dari penyidikan Polri penuntutan oleh Jaksa, hingga pembelaan oleh pengacara dan hakim sebagai pemutus akhir. Semua pihak bisa memainkan peran "Fakta direkam media massa bahwa penanganan kasus pembalakan liar ditandai oleh perseteruan antara Polri dengan Menteri Kehutanan. Bahkan dalam persidangan kasus Adelin, Menteri Kehutanan MS Ka'ban ikut menulis surat kepada pengacara Adelin: bahwa pelanggaran dalam kasus itu adalah pelanggaran administratif. Surat itu digunakan pengacara, dan pendapat Menhut diadopsi hakim menjadi suatu putusan yang melukai rasa keadilan masyarakat (Kom-pas, 2007:6).

Terdapat beberapa pihak yang menengarai jika peran KPK yang berlebihan tidak segera diantisipasi tidak saja akan berdampak pada timbulnya kecemburuan di lembaga penegak hukum yang lebih dulu berperan dan sistem pidana Indonesia (Indonesian Criminal Legal System), melainkan akan berpengaruh pada proses deligitimisasi institusi penegak hukum. Hal ini didasarkan kepada, pertama KPK sebagai institusi terobosan (breaking through) terhadap kemandegan kredibilitas penegak hukum di Indonesia, yang sampai hari ini tidak dibatasi pemberlakuannya.Kedua, timbulnya konflik intemal penegak hukum akibat peran luar biasa KPK juga tidak akan memberikan jaminan efisiensi dan efektiftas dari ketiga lembaga tersebut. Apalagi indikasi, sebagaimana disebutkan di atas, bahwa lembaga penegak hukum juga terlibat dalam tindak pidana korupsi. Ketiga, secara khusus, terdapat kecenderungan kedudukan peran Polri, dalam penyelidikan dan penyidikan termasuk, penggunaan inteligensi polisi dalam persoalan tindak pịdana korupsi semakin tereliminir oleh peran KPK berduet dengan Kejaksaan Agung. Hal ini terbukti dengan kenyataan bahwa KPK dan Kejagung belum mampu melaksanakan tugasnya kecuali menangkap koruptor kelas-kelas teri. Memprihatinkan lagi ketika, justru terdapat kerjasama dalam kaitannya dengan menciptakan krouptor kelas kakap menjadi raib dari tanah air (Antara News, 2007:3).

Kedua, KPK memiliki tantangan yang berat karena kepercayaan masyarakat dengan kesan tebang pilih dilakukan KPK 
belum pupus. Apalagi hasil KPK untuk mengembalikan uang negara dan dapat dipergunakan untuk kesejahteraan rakyat memang masih merupakan impian belaka. Dalam beberapa media, menyebutkan bahwa jumlah pengeluaran dan biaya operasional dari KPK melebih 1 (satu) Trilyun rupiah, sementara hasil yang diperoleh baru sekitar ratusan milyard. Misalnya, dalam tahun ke II KPK telah menemukan 70 kasus dugaan korupsi di Departemen Sosial dengan nilai Rp 287.89 Milyar. Dari jumlah tersebut sekitar 63 kasus dengan nilai 189.28 miliar telah ditindak lanjuti (Antara News, 2007:2). Sama halnya peran KPK terkait dengan temuan Audit BPKP dimana terdapat kerugian negara sebanyak 2.5 Trilyun sejak 2006 belum ada tindak lanjut. Pada tahun 2006, Audit BPKP menemukan adanya dugaan korupsi sebanyak 181 kasus sehingga negara dirugikan sebesar Rp 666,69 Trilyun. Hanya sebagian kecil telah dilakukan proses hukum yaitu dari 146 kasus baru 32 kasus dan hanya 3 kasus saja yang telah diputus.

Keterlambatan ini tentu saja terkait dengan selain, persoalan terbatasnya tenaga penyidik, (yang saat ini sedang dibutuhkan sekitar 30 orang) juga sistem pembuktian dalam kasus korupsi d pengadilan tidaklah cukup mudah. Memang keterlambatan ini juga tidak dapat ditudingkan kepada KPK, sebab sangat tergantung kepada lembaga negara itu sendiri. Misalnya, Anwar Nasution baru saja melaporkan adanya penyelewengan di $\mathrm{BI}$ kepada KPK. Aliran dana dari BI ke penegak hukum sebesar 68.5 milyar sejak tahun 1999 hingga 2004 juga belum ada tindak lanjut (Kompas, 2007:15). Atas dasar itu, jelaslah bahwa kedudukan KPK dengan fungsi yang memiliki kewenangan luas juga menjadi tidak mampu meyakinkan peran profesionalnya oleh karena tantangan dari masyarakat dan juga mengabaikan sifat kerjasama kolegial dengan pihak kepolisian dalam konteks penyelidikan dan penyidikan tidak dilakukan secara optimal.

Ketiga, tantangan KPK ke depan karena timbulnya kompleksitas hubungan fungsional antara lembaga negara yang terkait dengan pemberantasan korupsi. Hal yang perlu mendapatkan perhatian utama dalam membangunan pemeritahan yang baik dan bersih. Keberadaan KPK di tingkat pusat dengan keterbatasan struktur dan fungsi KPK secara organisatoris mustahil dapat diandalkan. Misalnya, bagaimana peran KPK dapat meningkat sekiranya pelayanan standar kriminal bagi masyarakat menuntut untuk dilayani. Misalnya, percepatan di bidang pekayanan publik (percepatan layanan identitaas, layanan kepolisian, layanan pertanahan, layanan usaha dan penanaman modal, layanan kesehatan, layanan perpajakan, layanan pendidikan, layanan transportasi, dan layanan utilitas dan layanan usia senja.

Dalam konteks ini diuapayakan layanan pemerintah dapat dilakukan dengan tanpa birokrasi yang berbelit-belit, dan juga proses pencepatan tanpa ada penyapan. Selain itu, tantangan yang tidak kalah pentingnya bagi jumlah anggota KPK adalah berkaitan dengan penetapan Tolok Ukur.Keberhasilan sesuai dengan Inpres No 5 tahun 2004 tentang Kordinasi Monitoring dan Evaluasi terkait dengan Pencepatan Pemberantasan Korupsi. Hal tersebut antara lain; (a) Memberikan gambaran yang jelas tentang program yang dilaksanakan, (b) menciptakan kesepakatan untuk menghindari kesalahan interpretasi selama pelaksanaan program /aktivitas (c) membangun dasar bagi pemantauan dan evaluasi (d) memotivasi pelaksana program dalam pencapaian hasil (e) mengkomunikasikan hasil kepada stakeholders. 


\section{Menguatkan Peran Polri dalam Pemberantasan Korupsi}

Dalam banyak literatur peran dan fungsi kepolisian hampir disejajarkan, sebagai Law and Order. Suatu teori yang menjelaskan bahwa polisi sebagai abdi negara memberikan pelayanan kepada masyarakat, antara lain menjaga (to prevent ) atau melindungi (to protect), melayani (to serve) dan menerapkan hukum (to enforce rule of law) dalam segala aspek agar kelangsungan hidup warga masyarakat dapat berjalan dengan tertib, aman dan sejahtera. Selain itu, polisi dapat memfasilitasi timbulnya sengketa agar ada proses hukum di pengadilan. Akan tetapi, menurut Satjipto Rahardjo peran kepolisian saat ini jauh lebih dituntut dekat dengan masyarakat oleh karena perkembangan hukum yang progresif menuntut polisi dan masyarakat selalu proaktif dan progresif dalam memelihara ketertiban dan kenyamanan hidup dalam masyarakat. Termasuk di dalamnya kemampuan untuk melakukan lobi dan negosiasi dengan kekuatan gerakan civil society.

Adapun beberapa argumen mengapa konsep dan strategi pemberantsan korupsi melalui pemberdayaan peran dan fungsi Polri sangat signifikan dan antisipatif. Terdapat empat hal yaitu landasan filosofis dan konstitusional, UUD 1945 dan pendekatan juridis, pendekatan hukum internasional dan kewilayahan, dan ketiga pendekatan kelembagaan yang profesional, dan terakhir pendekatan sosio-kultural kemasyarakatan.

Pertama, pemberdayaan Polri dalam pemberantasan tindak pidana korupsi tidak saja didukung oleh peran untuk selalu aktif dalam penyelematan uang negara, tetapi juga peran perlindungan dan pendidikan kepada masyarakat tentang terjaminnya ketertiban. Dalam UUD 1945, dengan sebutan Kepolisian Negara Republik Indonesia dari pusat dan daerah memiliki tugas pokok: (1) memelihara keamanan dan ketertiban masyarakat, (2) menegakan hukum, (3) memberikan perlindungan, pengayoman dan pelayanan pada masyarakat.

Dalam melaksanakan fungsi dan tugasnya kepolisian, maka Polri mempunyai tugas sebagai beriktut:

a. Melaksanakan pengaturan, penjagaan, pengawalan, dan patroli terhadap kegiatan masyarakat dan pemerintah sesuai kebutuhan.

b. Menyelenggarakan segala kegiatan dalam menjamin keamanan, ketertiban, dan kelancaran lalu lintas di jalan.

c. Membina masyarakat untuk meningkatkan partisipasi masyarakat serta ketaan warga masyarakat terhadap hukum dan peraturan perundangundangan.

d. Turut serta dalam pembnaan hukum nasional.

e. Memelihara ketertiban dan dan menjamin keamanan umum.

f. Melakukan koordinasi, pengawasan, dan pembinaan teknis terhadap kepolisian khusus, penyidik pegawai negeri sipil, dan bentuk pengamanan swakarsa.

g. Melakukan penyelidikan dan penyidikan terhadap semua tinda pidana sesuai Hukum Acara Pidana dan peraturan perundang-undangan lainnya (Untung, 2003:151).

Atas dasar poin $\mathrm{g}$ di atas kedudukan dan peran polisi dalam konteks pemberdayaan pemberantasan tindak korupsi tidak dapat dihindarkan. Sebab, istilah semua menunjukan bukti. bahwa polisi memiliki kewenangan profesional dan kompeten dalam melakukan pemnyelidikan dan penyidikan persoalan tindak pidana korupsi. 
Prospek Pemberantasan Korupsi: Perimbangan Kewenangan...; Jawahir Thontowi

Sekiranya dihadapkan pada UU No. 30 tahun 2002 , khususnya pasal $43 \mathrm{~s} / \mathrm{d}$ pasal 50 UU KPK, maka kewenangan tersebut tidak dapat menghilangkan fungsi dan kewenangan Polri. Sebab, di satu pihak bahwa menurut UU No. 10 tahun 2004, tentang Pembentukan Perautran Perundang-Undangan, pada dasarnya semua UU adalah saman derajatnya. Kecuali, memang UU KPK merupakan UU yang dapat menundukan ketentuan hukum dalam UU lainnya. Sehingga jika UU KPK dapat dikatakan sebagai lex specially dirogat generally, maka adalah jelas tidak memungkinkan diberlakukan. Jalan pemecahannya harus dilakukan hubungan peran kelembaan secara kolegial agar kedua UU ini dapat berlaku. Dalam UU No. 2 tahun 2002 tentan Undang Undang kepolisian dengan jelas dinyatakan demikian. Misalnya dalam pasal 14 ayat (1) dengan jelas memerinci tugas dan fungsi kepolisian dalam penyelidikan dan penyidikan. Dalam Hukum Acara Pidana, maka tugas penyelidikan dan penyidikan harus meliputi lima hal:

1. Mencari dan menemukan suatu peristiwa yang diduga sebagai tindak pidana. (korupsi adalah dikualifikasikan sebagai tindak pidana)

2. Menentukan dapat atau tidak dilakukan penyidikan

3. Mencari dan mengumpulkan bukti;

4. Membuat terang tentang tindak pidana yang terjadi

5. Menemukan tersangka pelaku tinda pidana (UU No.2,2002).

Pasal ini memang agak berbenturan dengan Bab II UU 30/2002, mengenai tugas dan kewajiban KPK. Akan tetapi, pasal tersebut tidak dapat mengeliminir tugas kepolisian dalam penyelidikan dan penyidikan tindak pidana korupsi. Hal ini dasarkan kepada fakta bahwa korupsi selain kejahatan luar biasa, tetapi juga secara

faktual juridis adalah tindak pidana yang juga telah lama diatur dalam KUHP.

Kedua, pemberdayaan peran Polri dalam konteks tindak pidana korupsi menjadi sangat signifikan oleh karena kejahatan korupsi hampir kebanyakan melibatkan suatu kekuatan kejahatan lintas negara (transnational organized crimes). Artidjo Alkostar, dengan tegas menyoroti kejahatan korupsi sebagai kejahatan global hal ini disebabkan karena konsekuensi logis meunculnya lembaga kontrol melintasi batas batas negara sebagai manifestasi dari perhatian masyarakat internasional. Sehingga PBB pada tanggal 30 Oktober 2003, menyetujui Konvensi Anti Korupsi yang mempunyai implikasi bagi negaranegara di dunia ketiga untuk memperjuangkan fungsi imperatifnya bagi pihak-piak yang melakukan korupsi yang sangat melukai rasa keadilan rakyat miskin di dunia (Artidjo Alkostar,2007:46).

Karena sifat tindak pidana korupsi mengglobal, maka proses penyelidikannya itupun tidaklah semua institusi negara dapat melakukannya. Dalam konteks ini KPK yang semula dapat dan memiliki kewenangan luar biasa dalam tingkat jurisdiksi nasional, tetapi dalam konteks kejahatan korupsi sebagai kejahatan lintas negara mejadi kurang dapat diandalkan. Fakta inilah yang kemudian memberikan peluang bagi pembedayaan peran Polri dalam permberantasan korupsi. Tidak diragukan peluang peran Polri dalam korupsi inilah oleh karena korupsi juga memiliki kesederajatan bobot kejahatan sebagaimana yang lainnya. Keluasan korupsi ini, diberikan ilustrasi oleh Barda Nawai Arief bahwa aspek korupsi itu antara lain terkait dengan kejahatan ekonomi (economic crimes), kejahatan teroganisir (organized crimes), kejahatan penyalahgunaan obat terlarang (illicit drug trafficking), kejahatan pencucian uang (money 
laundering), kejatan kerah putih (white collar crimes), kejahatan politik (political crimes), dan juga kejahatan lintas negara (transnational crime) (Nawawi,2007:131).

Dalam konteks global, peran Polri dalam pemberantasan korupsi ini memang tidak lepas dengan pentingnya kerjasama kolegial ke dalam institusi penegak hukum dalam sistem hukum nasional Indonesia. Tidak kalah pentingnya adalah kerjasama ke luar negeri yang hanya mungkin peran Polri dan diplomasi itulah menjadi peluang yang begitu besar. Relevan untuk dipertimbangkan pandangan Todung Mulya Lubis, bahwa Indonesia sudah perlu mengambil kepemimpinan ASEAN terkait dengan Konvensi Anti Korupsi ASEAN. Sebab, jika pemerintah Rl khususnya Presiden SBY akan ikut ambil bagian penting untuk mengusulkan agar pemberantasan korupsi, dimasukan menjadi agenda besar ASEAN (Kompas, November, 2007:6). Tentu saja peran kepolisian akan semakin terlihat dalam memainkan peranannya secara global melalui interpolnya, terutama terkait dengan kejahatan korupsi, terorisme dan sejenisnya.

Ketiga, pemberdayaan peran Polri dalam pemberantasan korupsi akan menjadi sangat signifikan bilamana diwacanakan tentang pentingnya suatu lembaga khusus dalam hal penyelidikan dan penyidikan, baik dalam konteks jurisdiksi nasional maupun jursidiksi internasional terkait dengan kejahatan korupsi. Hal ini menjadi sangat penting oleh karena pengalaman menujukan bahwa kejahatan terorisme sebagai kejahatan luar biasa dan kejahatan kemanusiaan menjadi cukup berdaya tingkat dan kualitas kerjanya setelah UU No. 15/2003 tentang tindak Pidana Kejahatan Terorisme disahkan. Kemudian dari situ, diberlakukan dan dibentuk suatu Tim Datasemen 88 , sebagai suatu unit profesional dan kompeten untuk melakukan pemberantasa terhadap kejahatan teroris. Bukti ini telah ditujukan dan kar4ena pelecehan yang selama ini pihak lain memadang Polri tidak tangguh dan profesional terbukti di lapangan sebaliknya memiliki kemampuan.

Tidak berbeda dengan persoalan tindak pidana korupsi perlu dibangun suatu gagasan akan terbentuknya suatu Tim tersendiri, semacam Tim Penyelidik dan Penyidik Kejahatan Korupsi yang secara kompeten dan profesional akan berkiprah dalam pemberantasan korupsi. Jumlah anggota kepolisian, yang saat ini, hampir 600.000 orang merupakan potensi yang dapat diandalkan dalam proses mempercepat pemberantasan korupsi. Secara struktural, lebih dari ribuan Kapolsek, (Kepala Polisi Sektor) di setiap kecamatan merupakan institusi terbawah yang dapat membantu proses penyelidikan dan penyidikan dalam kasus korupsi. Karena itu, keberadaan peran Polri dalam pemberantasan tindak korupsi jelas signifikan untuk diberdayakan mengingat SDM penyidik KPK masih terbatas.

Untuk mencapai pemberdayaan Polri yang berhasil perlu adanya konsolidasi kelembagaan di antara penegak hukum sendiri. Termasuk, perlunya pembatasan wilayah kerja masing-masing antara $\mathrm{KPK}$, Kejaksaan Agung dan juga Kepolisian. Untuk menjadikan Tim Task Force, maka SDM Polri di tingkat daerah juga perlu ditingkat pengetahuan dan pengalaman dalam persoalan Hukum Acara Pidana tindak pidana korupsi. Tidak mengherankan juga dalam kenyataan, misalnya, apakah tidak sebaiknya jika, KPK bertugas untuk menjalankan fungsi penegakan hukum ditujukan kepada pejabat, khusunya pejabat penegak hukum. Hal ini menjadi sangat logis secara juridis, bilamana KPK yang independen tersebut hanya ditugaskan 
untuk melakukan tindakan sebatas pejabat penegak hukum. Polri mungkin dapat diarahkan pada pemberantasan korupsi untuk pejabat sipil pada umumnya termasuk juga bisnismen yang memang terlibat dalam kejahatan korupsi. Rasa pakewuh antara sesama kesatuan untukmenegakan hukum terbukti tidak dapat dihindari. Hal ini, secarà implisit terkait ketika KPK yang lalu, Taufiqurrahman Ruki tidak secara tegas menangkap Rusdihardjo Mantan Duta Besar melakukan penangkapan. Bahkan, meskipun berkali kasus Rusdihardjo telah masuk sejak tahun lalu dalam keanyataan baru akhir ini diketahui publik.

\section{Penutup}

Uraian tersebut di atas mengindikasikan dengan jelaslah bahwa upaya ke arah Pencepatan Pemberantasan Tindakan Pidana Korupsi yang diperankan oleh Polri tidaksangat signifikan. Adapun argumentasi yang dapat dikemukakan antara sebagai berikut:

Pertama, sistem hukum nasional terkait dengan upaya melakukan pemberantasan korupsi sesungguhnya bukan sesuatu yang baru. Terbukti dalam KUHP, UU Korupsi dan juga sampai dengan lahirnya UU No. 30 tahun 2002, tentang Komisi Tindak Pidana Korupsi juga telah dișepakati dengan pendekatan instrumen hukum lainnya, termasuk pelaporan harta kekayaan pejabat negara. Namun, efektivitas dari instrumen hukum tersebut ternyata belum dapat memberikan dampak positif terhadap terbangunya pemerintah yang baik dan bersih (good govemance and clean govemment). Persoalan tindak pidana korupsi bukan sekedar fenomena ekonomi semata, tetapi terkait dengan fenomena politik, budaya, hukum dan juga karena warisan nilai-nilai intistitusi pemerintahan itu sendiri yang cenderung menyimpang (corrupt) di masa lalu yang juga masih berpengaruh sampai saat ini.

Kedua, KPKyang selama ini dipandang sebagai superbodydalam penegakan tindak pidana korupsi diakui telah membuktikan fungsi dan kewenangannya dan masyarakat menyambut baik akan langah-langkah strategis KPK. Namun, peran dan fungsi yang memiliki extra powertersebut ternyata dalam waktu yang sama pula menimbulkan konflik kelembagaan. Timbulnya kecemburuan diantara lemabaga lembaga penegak hukum, seperti polisi, kejaksaan, peradilan dan bahkan eksekutif tidak dapat ditepis sehingga kredibilitas dan sifat kewenangan. kewenagan istimewa yang dimiliki KPK terus menuai pro-kontra. Tidak dapat dicegah, kemudian keterbatasan KPK dalam bidang penyelidikan dan penyidikan menjadi kurang profesional dan kompeten karena antara jumlah kasus yang ada dengari keterbatasan SDM menjadi faktor melemahnya kapasitas tersebut. Apalagi, indikasi untuk tidak melibatkan Polri dalam konteks penyelidikan dan penyidikan dalam kejahatan korupsi mestinya menjadi daya dorong kedua lembaga ini terbukti tidak terjadi adanya kerjasama kolegial.

Ketiga, Tim Task Force, seidentik dengan Detasemen 88 untuk kejahatan Terorisme, dalam kaitannya dengan upaya Pemberdayaan dan Pencepatan Pemberantasan Korupsi menjadi sangat strategis dan perlu menjadi program unggulan di Polri dua tahun ke depan. Kepentingan ini bukan saja terbuka karena sifat kejahatan korupsi dan konteks penyelidikan dan penyidikan secara profesional dan kompeten berada di tangan Polri. Sifat kejahatan korupsi yang mengglobal tetapi menimbulkan ancaman bagi keutuhan bangsa dalam arti kesejahteraan ekonomi masyarakat dan negara terbukti tidak dapat hanya dapat diberantas 
dan diperangi oleh sistem hukum pidana yang biasa (ordinary crime). Lebih penting dari itu, peluang Polri dalam konteks ini adalah karena kejahatan korupsi telah menjadi kejahatan lintas negara dimana cara penanganannya tidak mungkin KPK. Hanya dengan memberdayakan peran polisi dari tingkat internasional sampai dengan institusi lokal para tindak pidana tidak dapat lari dari pertanggungjawaban dan keadilan.l

\section{Daftar Pustaka}

Farouk Muhammad.2007. Reformasi Sistem Peradilan Pidana. Aspek Kepolisian. BHN-UNSRI,SumatraSelatan. 3-4 April.

UU Nomor 30 tahun 2002 tentang Komisi Pemberantasan Tindak Pidana Korupsi.

Atmasasmita,Romli .2004. Kajian komprehensif dan mendalam tentang Tindak Pidana Korupsi dalam tulisan. Sekitar Masalah Korupsi: Aspek Nasional dan Aspek Intemasional. Bandung: Mandar Maju.

Oemarmadi,Sarwedi. (dkk),2005. Tool Kit Anti Korupsi, Lima Belas Langkah Pengadaan Barang dan Jasa Pemerintah, Indonesia Procurement Watch-Hivos.

Kamri A. Korupsi, 2005. Pidana Mati dan HAM. Dalam Muladi. Hak Asasi Manusia: Hakekat, Konsep dan Implikasnya Dalam Perspektif Hukum dan Masyarakat. Bandung: Refika Aditama
Tajuk Rencana KOMPAS. Awal dan Akhir Adelin Lies. Jumat, 9 November 2007: 6.

ANTARA NEWS, 18 Juni 2007. hal 3.

Lihat keterangan dari dan informasi dari ANTARA NEWS, Juni 2007. hal 2.

KOMPAS melaporkan' "Aliran dana ke penegak hukum". 10 November 2007: Hal 15.

Untung S. Rajab.2003. Kedudukan dan Fungsi Polisi Republik Indonesia Dalam Sistem Ketatanegaraan (Berdasarkan UUD 1945). Bandung: Utomo.

Alkostar,Artidjo.2007. Ulasan tentang korelasi korupsi dengan penegakan secara interdisipliner dalam karya Korelasi Korupsi Politik Dengan Hukum dan Pemerintahan di Negara Moderen (Telaah tentang Praktek Konupsi Politik dan Penanggulangannya). Ringkasan Disertasi.Semarang: Program Doktor Ilmu Hukum Universitas Diponegoro.

Nawawi Arie,Barda. 2007. Masalah Penegakan Hukum dan Kebijakan Hukum Pidana dalam Penanggulangan Kejahatan. Jakarta: Kencana Prenada Media.

Mulya Lubis, Todung. Konvensi Antikorupsi ASEAN. KOMPAS. Jumat 9 November 2007. 